\title{
STUDI LITERATUR: PENERAPAN KOMUNIKASI TERAPEUTIK TERHADAP PSIKOLOGIS LANSIA
}

\author{
Alfiery Leda Kio ${ }^{1}$, I Ketut Andika Priastana ${ }^{2}$ \\ STIKES Bina Usada Bali ${ }^{1}$ \\ Universitas Triatma Mulya ${ }^{2}$ \\ e-mail: ${ }^{2}$ iketutandikapriastana@gmail.com
}

\begin{abstract}
Elderly is the last period in human life. The elderly have various health problems related to the aging process, one of which is psychological disorders. Efforts to improve the psychological health of the elderly can be done in various ways, one of the efforts that can be done is by applying therapeutic communication. This study aims to determine the application of therapeutic communication to the psychology of the elderly. The research method uses the Literature Review method with secondary data collection from scientific research articles from 2011 2021. Search data using Google Scholar, Crossref, Indonesia OneSearch and Garuda databases online using key words namely therapeutic communication, psychological, elderly. The articles obtained were 184 articles, but only 5 articles that matched the inclusion criteria. Selected articles are then evaluated. This literature study found that therapeutic communication has a positive impact in reducing psychological disorders in the elderly including anxiety, depression levels, and cognitive disorders. Therapeutic communication used by nurses has characteristics, namely attention, planned communication, to know, observation, appreciation and humor, taboo communication, respect, care, clarity, empathy and building relationships. Nurses are very important in implementing therapeutic communication in carrying out nursing services, especially for the elderly who experience psychological disorders to rebuild interpersonal relationships with the elderly so that the elderly are able to improve psychological conditions to an optimal stage to achieve a good quality of life in old age.
\end{abstract}

Keywords: therapeutic communication, psychological, elderly, literature review

\begin{abstract}
ABSTRAK
Lansia adalah masa terakhir dalam kehidupan manusia. Lansia memiliki berbagai masalah kesehatan berkaitan dengan proses menua, salah satunya yaitu gangguan psikologis. Upaya untuk meningkatkan kesehatan psikologis lansia dapat dilakukan dengan berbagai cara, salah satu upaya yang dapat dilakukan adalah dengan penerapan komunikasi terapeutik. Penelitian ini bertujuan untuk mengetahui penerapan komunikasi terapeutik pada psikologis lansia. Metode penelitian menggunakan metode Literature Review dengan pengumpulan data sekunder dari artikel penelitian ilmiah dari tahun 2011-2021. Pencarian data menggunakan database Google Scholar, Crossref, Indonesia OneSearch dan Garuda secara online dengan menggunakan kata-kata kunci yakni komunikasi terapeutik, psikologis, lansia. Artikel yang diperoleh sebanyak 184 artikel, tetapi yang sesuai dengan kriteria inklusi hanya 5 artikel. Artikel terpilih kemudian dilakukan evaluasi. Studi literatur ini menemukan bahwa komunikasi terapeutik memberikan dampak positif dalam penurunan gangguan psikologis pada lansia diantaranya kecemasan, tingkat depresi, dan gangguan kognitif. Komunikasi terapeutik yang digunakan perawat memiliki ciri khas yaitu perhatian, komunikasi yang direncanakan, untuk mengetahui, observasi, apresiasi dan humor, komunikasi tabu, menghormati, peduli, kejelasan, empati dan membangun hubungan. Perawat sangat penting menerapkan komunikasi terapeutik dalam melaksanakan pelayanan keperawatan khususnya pada lansia yang mengalami gangguan psikologis untuk membangun kembali hubungan interpersonal dengan lansia sehingga lansia mampu meningkatkan kondisi psikologis ke tahap yang optimal untuk tercapainya kualitas hidup yang baik di masa tua.
\end{abstract}

Kata kunci: komunikasi terapeutik, psikologis, lansia, studi literatur 


\section{Vol. 16 No.2 Mei - Agustus 2021}

\section{PENDAHULUAN}

Lansia adalah masa terakhir dalam kehidupan manusia (1). Lansia memiliki berbagai masalah kesehatan berkaitan dengan proses menua, salah satunya yaitu gangguan psikologis (2). Gejala psikologis pada lansia dapat berupa rasa takut, cemas, tegang, stress, depresi, mudah sedih, cepat merasa marah, mudah tersinggung, gugup dan keadaan mental yang tidak stabil. Perubahan yang terjadi terhadap mental/psikologis lansia berupa sikap yang semakin egosentrik, mudah curiga dan bertambah pelit atau tamak bila memiliki sesuatu, ingin mempertahankan hak dan hartanya serta ingin tetap berwibawa, dan mengharapkan tetap diberi peranan dalam masyarakat (3).

Salah satu cara yang dapat dilakukan untuk mengatasi gangguan psikologis di masa tua adalah dengan komunikasi terapeutik. Komunikasi merupakan elemen dasar dari interaksi manusia yang memungkinkan seseorang untuk menetapkan, mempertahankan dan meningkatkan kontrak dengan orang lain karena komunikasi dilakukan oleh seseorang, setiap hari orang seringkali salah berpikir bahwa komunikasi adalah sesuatu yang mudah. Namun sebenarnya adalah proses yang kompleks yang melibatkan tingkah laku dan hubungan serta memungkinkan individu berasosiasi dengan orang lain dan dengan lingkungan sekitarnya. Hal itu merupakan peristiwa yang terus berlangsung secara dinamis yang maknanya dipacu dan ditransmisikan. Untuk memperbaiki interpretasi pasien terhadap pesan, perawat harus tidak terburu-buru dan mengurangi kebisingan dan distraksi. Kalimat yang jelas dan mudah dimengerti dipakai untuk menyampaikan pesan karena arti suatu kata sering kali telah lupa atau ada kesulitan dalam mengorganisasi dan mengekspresikan pikiran. Instruksi yang berurutan dan sederhana dapat dipakai untuk mengingatkan pasien dan sering sangat membantu (4).

Komunikasi merupakan hal yang sangat penting dalam proses pemberian asuhan keperawatan. Komunikasi yang terjalin baik akan menimbulkan kepercayaan sehingga terjadi hubungan yang lebih hangat dan mendalam, kehangatan suatu hubungan akan mendorong pengungkapan beban perasaan dan pikiran yang dirasakan oleh klien yang dapat menurunkan tingkat depresi yang terjadi (5).
Komunikasi terapeutik memberikan efek yang dapat membangkitkan serta mengingatkan pada masa lalu yang dianggap memiliki kenangan tersendiri bagi seseorang, sehingga otak menjadi rileks dan memberikan efek terapeutik yang membantu dalam penurunan gangguan psikologis.

Komunikasi pada lansia membutuhkan perhatian khusus. Perawat harus waspada terhadap perubahan fisik, psikologi, emosi, dan sosial yang memperngaruhi pola komunikasi. Perubahan yang berhubungan dengan umur dalam sistem auditoris dapat mengakibatkan kerusakan pada pendengaran. Perubahan pada telinga bagian dalam dan telinga mengalangi proses pendengaran pada lansia sehingga tidak toleran terhadap suara (6).

Komunikasi terapeutik merupakan komunikasi khusus yang dilaksanakan oleh tenaga kesehatan dalam hal ini perawat dan tenaga kesehatan yang lain yang direncanakan dan berfokus pada pasda kesembuhan klien. Hubungan antara perawat dan pasien yang bersifat terapeutik karena komunikasi yag dilakukan dengan tujuan memperbaiki emosi. Perawat menjadikan dirinya secara terapeutik dengan berbagai tekhnik komuikasi secara optimal dengan tujuan untuk mengubah perilaku klien ke arah positif (7).

Gangguan psikologis pada lansia akan sangat mengganggu lansia dalam menjalani masa tua. Perawat penting hadir memberikan komunikasi terapeutik dalam upaya menurunkan gangguan psikologis tersebut. Oleh karena itu, penelitian ini mengulas penerapaan komunikasi terapeutik terhadap gangguan psikologis lansia berdasarkan studi literatur.

\section{METODE}

Metode penelitian menggunakan metode Literature Review dengan pengumpulan data sekunder dari artikel penelitian ilmiah. Pencarian data menggunakan database Google Scholar, Crossref, Indonesia OneSearch dan Garuda secara online dengan menggunakan kata-kata kunci yakni komunikasi terapeutik, psikologis, lansia. Kriteria inklusi dalam penelitian ini adalah artikel diterbitkan sepuluh tahun terakhir (2011-2021), jenis penelitian original research, full text dapat diakses, dan berbahasa Indonesia. Artikel yang diperoleh sebanyak 184 artikel, tetapi yang sesuai dengan kriteria inklusi hanya 5 artikel. Artikel terpilih kemudian dilakukan evaluasi. 
HASIL

Studi literatur ini menemukan bahwa komunikasi terapeutik memberikan dampak positif dalam penurunan gangguan psikologis pada lansia diantaranya kecemasan, tingkat depresi, dan gangguan kognitif. Komunikasi terapeutik yang digunakan perawat memiliki ciri khas yaitu perhatian, komunikasi yang direncanakan, untuk mengetahui, observasi, apresiasi dan humor, komunikasi tabu, menghormati, peduli, kejelasan, empati dan membangun hubungan.

\begin{tabular}{llr}
\hline No & \multicolumn{2}{l}{ Judul Artikel/Penulis } \\
\hline 1 & \multicolumn{2}{l}{ Pengaruh Komunikasi } \\
& Therapeutik & terhadap \\
& Kemampuan & \\
& Kognitif & Lansia \\
& Demensia $\quad$ di & Desa \\
& Dasan & Geria \\
& Kecamatan & \\
& Lingsar Kabupaten \\
& Lombok Barat \\
& (I Made Eka Santosa, \\
& 2017)
\end{tabular}

\section{Sumber}

PrimA: Jurnal

Ilmiah Ilmu

Kesehatan,

Vol. 3, No. 2

\section{Metode Penelitian}

Pre-eksperimental

sampel 20 orang dengan jumlah

\begin{tabular}{ll}
\hline 2 & Hubungan Komunikasi \\
& Terapeutik \\
& dengan Tingkat Depresi \\
& Lansia di \\
& PSTW Budi Sejahtera \\
& Banjarbaru \\
& Provinsi Kalimantan \\
Selatan \\
(Abdullah \& Linda, \\
2018)
\end{tabular}

\section{Temuan}

Hasil penelitian menunjukkan bahwa nilai t-hitung lebih besar dari t tabel $(19,624>1,729)$ maka Ho ditolak, artinya ada pengaruh komunikasi terapeutik terhadap tingkat kemammpuan kognitif lansia demensia di Dusun Gegutu Reban Kecamatan Lingsar Kabupaten Lombok Barat. Berdasarkan hasil penelitian, perawat sebagai care provider disarankan untuk mengaplikasikan komunikasi terapeutik sebagai salah satu intervensi bagi lansia yang mengalami gangguan kognitif demensia (pikun).

2-TRIK: Cross-sectional Hasil uji korelasi Spearman
Tunas-Tunas dengan jumlah menunjukkan $p$-value $=0,44$ sehingga Riset sampel 111 orang Kesehatan,

Vol. 8, No. 2 dapat diinterprestasikan terdapat hubungan antara komunikasi terapeutik dengan tingkat depresi dengan koefisien korelasi $=-0,320$ berarti kekuatan hubungan antara komunikasi terapeutik dengan tingkat depresi pada lansia di PSTW Budi Sejahtera Banjarbaru Provinsi Kalimantan Selatan.

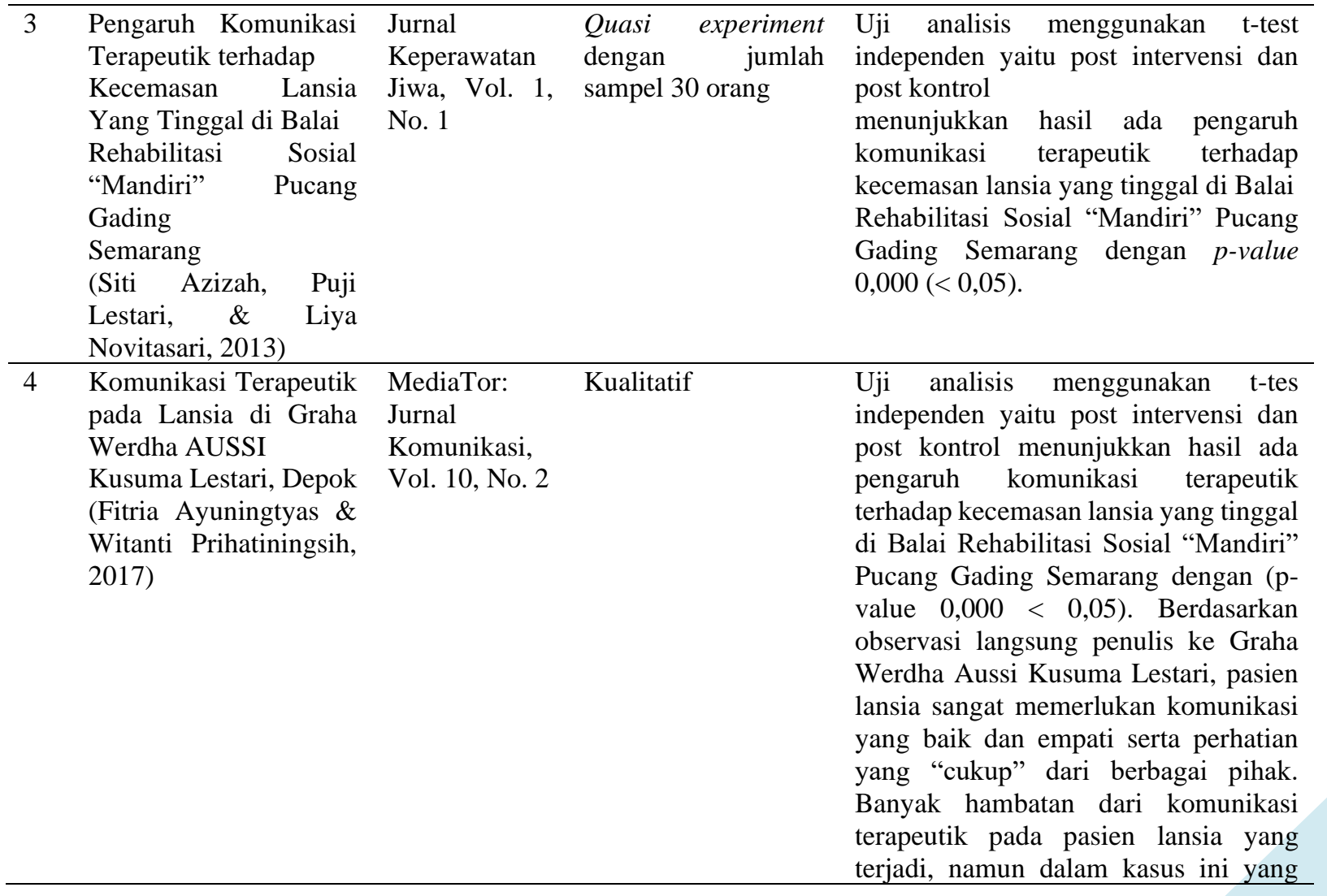




\section{Vol. 16 No.2 Mei - Agustus 2021}

\begin{tabular}{|c|c|c|}
\hline $\begin{array}{l}\text { Pengalaman } \\
\text { Komunikasi Terapeutik } \\
\text { Perawat Orang Lanjut } \\
\text { Usia } \\
\text { (Antar Venus \& Dina } \\
\text { Nabilah, 2016) }\end{array}$ & $\begin{array}{l}\text { Jurnal } \\
\text { Communicate, } \\
\text { Vol. } 1 \text {, No. } 2\end{array}$ & $\begin{array}{l}\text { Berdasarkan penelitian ini, ditemukan } \\
\text { sepuluh tema penting dalam terapi } \\
\text { berkomunikasi dengan pasien usia } \\
\text { lanjut, yaitu: komunikasi yang } \\
\text { direncanakan, untuk mengetahui, } \\
\text { observasi, apresiasi dan humor, } \\
\text { komunikasi tabu, menghormati, peduli, } \\
\text { kejelasan, empati dan membangun } \\
\text { hubungan. Sepuluh tema di atas kita } \\
\text { dibuat untuk tiga (3) hal yang menjadi } \\
\text { pembelajaran utama dan esensi dalam } \\
\text { penelitian ini. } 3 \text { (tiga) itu direncanakan, } \\
\text { peduli, dan empati merupakan jawaban } \\
\text { untuk pertanyaan penelitian. }\end{array}$ \\
\hline
\end{tabular}

\section{PEMBAHASAN}

Komunikasi terapeutik memberikan dampak positif dalam penurunan gangguan psikologis pada lansia diantaranya kecemasan, tingkat depresi, dan gangguan kognitif.

Komunikasi terapeutik memberikan efek yang dapat membangkitkan serta mengingatkan pada masa lalu yang dianggap memiliki kenangan tersendiri bagi responden, sehingga otak menjadi rileks dan memberikan efek terapeutik yang membantu dalam peningkatan status fungsi kognitif responden (8).

Komunikasi terapeutik dapat menurunkan tingkat kecemasan karena disadari ataupun tidak terbentuknya komunikasi terapeutik dapat menyediakan ruang yang aman bagi pasien untuk menjelaskan perasaan, harapan dan kecemasan serta menyediakan ruang bagi perawat untuk memberikan informasi dan emotional support serta dapat menciptakan suasana yang dapat memotivasi pasien sehingga dapat dicapai status kesehatan baik fisik maupun psikologis yang maksimal (10). Komunikasi terapeutik yang dibangun oleh perawat terhadap pasien akan mempengaruhi persepsi pasien terhadap suatu penampilan pelayanan yang diberikan perawat kepada pasiennya (13).

Komunikasi terapeutik yang terlaksana sangat dipengaruhi oleh rendahnya tingkat depresi dan penurunan tingkat depresi sangat dipengaruhi oleh terlaksananya komunikasi terapeutik pada lansia. Semakin terlaksana komunikasi terapeutik maka semakin menurunkan tingkat depresi dan sebaliknya banyak terjadi di Panti Werdha yaitu resisten. Perilaku resisten biasanya diperlihatkan pasien pada masa penyembuhan terhadap penyakit tertentu dikarenakan adanya rasa lelah, marah dan sedih terhadap penyakit yang dideritanya.

Berdasarkan penelitian ini, ditemukan lanjut, yaitu: komunikasi yang direncanakan, untuk mengetahui, observasi, apresiasi dan humor komunikasi tabu, menghormati, peduli, kejelasan, empati dan membangu dibuat untuk tiga (3) hal yang menjadi pembelajaran utama dan esensi dalam untuk pertanyaan penelitian. semakin rendah tingkat depresi semakin terlaksana komunikasi terapeutik (9).

Komunikasi yang terjalin dengan baik akan menimbulkan kepercayaan sehingga terjadi hubungan yang lebih hangat dan mendalam. Kehangatan suatu hubungan akan mendorong pengungkapan beban perasaan dan pikiran yang dirasakan oleh klien yang dapat menjadi jembatan dalam menurunkan tingkat depresi yang terjadi (5).

Komunikasi terapeutik yang digunakan perawat memiliki ciri khas yaitu perhatian, komunikasi yang direncanakan, untuk mengetahui, observasi, apresiasi dan humor, komunikasi tabu, menghormati, peduli, kejelasan, empati dan membangun hubungan $(9,12)$.

Para ahli komunikasi menyebut cara komunikasi yang dilakukan perawat tersebut merupakan komunikasi terapeutik yakni komunikasi yang ditujukan untuk memperkuat rasa aman, kesejahteraan, kebergunaan, kepercayaan, dan rasa mampu diri orang-orang lanjut usia yang dalam berbagai hal mengalami penurunan kemampuan dalam menjalani hidup (15).

\section{KESIMPULAN}

Studi literatur ini menemukan bahwa komunikasi terapeutik memberikan dampak positif dalam penurunan gangguan psikologis pada lansia diantaranya kecemasan, tingkat depresi, dan gangguan kognitif. Komunikasi terapeutik yang digunakan perawat memiliki ciri khas yaitu perhatian, komunikasi yang direncanakan, untuk mengetahui, observasi, 
apresiasi dan humor, komunikasi tabu, menghormati, peduli, kejelasan, empati dan membangun hubungan.

Perawat sangat penting menerapkan komunikasi terapeutik dalam melaksanakan pelayanan keperawatan khususnya pada lansia yang mengalami gangguan psikologis untuk membangun kembali hubungan interpersonal dengan lansia sehingga lansia mampu meningkatkan kondisi psikologis ke tahap yang optimal untuk tercapainya kualitas hidup yang baik di masa tua.

\section{DAFTAR PUSTAKA}

1. Syukkur A, Astrid M, Hastono SP. The Effect of Ginger Compress Therapy and Kinesiotaping on Pain and Stiffness in the Joints and Functional Ability in Elderly with Osteoarthritis. Babali Nurs Res. 2020;1(3):112-21.

2. Pendet NMDP, Yona S, Yulia. Depression, Stigma, and Quality Of Life among Elderly with HIV/AIDS in Bali. Babali Nurs Res. 2020;1(3):100-11.

3. Nugroho W. Keperawatan Gerontik \& Geriatrik. 3rd ed. Ester M, Tiar E, editors. Jakarta: EGC; 2008. 259 p.

4. Hinkle JL, Cheever KH. Brunner \& Suddarth's Textbook of Medical-Surgical Nursing. 13th ed. Philadelphia: Lippincott Williams \& Wilkins; 2014.

5. Tamsuri A. Buku Saku: Komunikasi dalam Keperawatan. Jakarta: EGC; 2016.

6. Faridah F, Indrawati I. Komunikasi Terapeutik Pada Lansia Di Panti Sosial Tresna Werdha Budi Luhur Jambi. J Abdimas Kesehat. 2019;1(2):117.

7. Suryani. Ilmu Komunikasi: Perspektif, Proses dan
Konteks. Bandung: Wijaya Padjajaran; 2012.

8. Santosa IME. Pengaruh Komunikasi Therapeutik terhadap Kemampuan Kognitif Lansia Demensia di Desa Dasan Geria Kecamatan Lingsar Kabupaten Lombok Barat. PrimA J Ilm Ilmu Kesehat. 2017;3(2):15-22.

9. Abdullah, Linda. Hubungan Komunikasi Terapeutik dengan Tingkat Depresi Lansia di PSTW Budi Sejahtera Banjarbaru Provinsi Kalimantan Selatan. 2-TRIK Tunas-Tunas Ris Kesehat. 2018;8(2):96-8.

10. Azizah S, Lestari P, Novitasari L. Pengaruh Komunikasi Terapeutik Terhadap Kecemasan Lansia Yang Tinggal Di Balai Rehabilitasi Sosial "Mandiri" Pucang Gading Semarang. J Keperawatan Jiwa. 2013;1(1):88-97.

11. Ayuningtyas F, Prihatiningsih W. Komunikasi Terapeutik pada Lansia di Graha Werdha AUSSI Kusuma Lestari, Depok. Mediat J Komun. 2017;10(2):201-15.

12. Venus A, Nabilah D. Pengalaman Komunikasi Terapeutik Perawat Orang Lanjut Usia. J Commun. 2016;1(2):75-86.

13. Machfoedz M. Komunikasi Keperawatan (Komunikasi Terapeutik). Jakarta: Ganbika; 2009.

14. Venus A, Nabilah D. Pengalaman Komunikasi Terapeutik Perawat Orang Lanjut Usia. J Commun. 2016;3(2):75-86.

15. Hammer M, Fox S, Hampton MD. Use of a Therapeutic Communication Simulation Model in Pre-Licensure Psychiatric Mental Health Nursing: Enhancing Strengths and Transforming Challenges. Nurs Heal. 2014;2(1):1-8. 